\title{
Biofield Therapy
}

National Cancer Institute

\section{Source}

National Cancer Institute. Biofield Therapy. NCI Thesaurus. Code C15910.

A form of therapy that involves systems using "subtle energy" fields in and around the body for medical/therapeutic purposes. Examples include Therapeutic Touch, Reiki, Huna, laying-on-of-hands, external Qi-Gong, Healing Science, Healing touch, Natural healing, Specific Human Energy Nexus (SHEN), and Bio-Relaxation. 